\title{
PERBANDINGAN LITERASI INFORMASI MAHASISWA PEMULA POLITEKNIK NEGERI BATAM
}

\author{
Maryani Septiana ${ }^{(1)}$,Aditya Wirangga ${ }^{(2}$ \\ Jurusan Manajemen Bisnis, Politeknik Negeri Batam \\ JL. Ahmad Yani Teluk Tering Batam Center Batam 2946I, Indonesia \\ Email: (I) maryaniseptiana@polibatam.ac.id, (2)wirangga@polibatam.ac.id,
}

\begin{abstract}
Abstrak
This study aims to compare the level of information literacy of first-year students across different studies offered by major at Polytechnic Negeri Batam. The method used is a descriptive quantitative approach through a questionnaire conducted to 93 respondents. The sampling method uses purposive sampling. This study takes ALA concept of information literacy. The results are shows that students of engineering major are higher than business management in information literacy's level. The level of information literacy of students are in good scale which is means that students are have information literacy competence to understand about their information needed, understand how to using the source of information, and understand about issue in society through the information they have. But, they are lacking of how to evaluate the information since digital technology are based on the learning process.
\end{abstract}

Keywords : Information Literacy, Comparative study, Higher students

\section{PENDAHULUAN}

Masyarakat Ekonomi Asean menjadi acuan Indonesia dalam mewujudkan bangsa yang sejajar dan bersaing secara internasional. Disamping itu, adanya 8 program pengembangan yang dinamakan The Millennium Development Goals (MDGs) yang dicanangkan oleh UNESCO tahun 2015 yang salah satunya adalah literasi informasi dan media untuk pengembangan berkelanjutan (Media and Information Literacy for Sustainable Development Goals) yaitu adanya akses pengetahuan dan informasi untuk semua warga negara dan pengembangan media, perpustakaan, internet dan penyediaan informasi lain. Hal ini sudah seharusnya menjadi sorotan manajemen pendidikan untuk melahirkan generasi yang siap bersaing dengan bangsa lain. Literasi informasi juga merupakan suatu hal yang penting dalam mengembangkan proses pendidikan dan agar tercipta lingkungan berbasis ilmiah. Melalui penguasaan informasi yang cepat tanggap dan baik dapat memberikan kepercayaan diri yang tinggi dengan persaingan ini. Literasi informasi bukan merupakan produk baru di Indonesia, banyak penelitian yang sudah dilakukan sebelumnya tentang mengukur bagaimana tingkatan literasi mahasiswa Indonesia. Riset yang dilakukan oleh Joner Siagian (2008) mengatakan bahwa penguasaan literasi informasi tidak hanya bertujuan untuk menjadikan mahasiswa sebagai individu yang information literate, yang mampu menyelesaikan tugas-tugas akademisnya dengan baik, tetapi juga untuk membekali mereka dengan pemahaman yang mendalam tentang literasi informasi karena merekalah nantinya yang akan menularkan dan mengajarkan kompetensi ini ke lingkungan kerjanya. Selain itu adanya penelitian yang dilakukan oleh Schuster (2007) pada mahasiswa 
bioteknologi mengatakan bahwa kegiatan literasi informasi merupakan tantangan dalam menciptakan kasus-kasus yang dapat dikembangkan oleh mahasiswa dan untuk mengintegrasikan penelitian dengan pendidikan sebagai cara dalam menciptakan ketertarikan dan stimulus untuk menciptakan lingkungan ilmiah dalam semua institusi (p.373).

Lokasi Politeknik Negeri Batam yang merupakan wilayah terluar menjadikan lulusannya juga harus dapat dan dituntut memiliki kemampuan literasi informasi yang bagus. Kemampuan ini yang dapat membantu mahasiswa untuk bersaing dengan bangsa lain. Politeknik Negeri Batam memiliki kesempatan lebih besar untuk mengembangkan program literasi informasi mengingat mahasiswa yang masuk merupakan pilihan dengan disertai adanya tes masuk yang dapat disejajarkan dengan kampus lain. Mahasiswa yang memiliki latar belakang pendidikan sekolah menengah umum maupun kejuruan akan terlihat bagaimana kompetensinya. Faktor lain yang juga melatarbelakangi perbedaan tingkatan literasi informasi adalah faktor psikologis, keluarga dan lingkungan sekitar. Faktor internal maupun eksternal menjadi latar belakang tingkatan literasi informasi yang dimiliki mahasiswa/i Politeknik Negeri Batam. Selain faktor yang sudah dijelaskan sebelumnya, budaya yang ada di Batam juga dapat mempengaruhi literasi informasi. Penelitian ini terkait dengan bagaimana kemampuan mahasiswa melihat informasi sebagai kebutuhan, mencari sumber informasi yang diinginkan melalui sumber buku, internet dan media lainnya, mengalokasikan informasi itu di dalam otak atau dengan penggunaan teknologi informasi, mengevaluasi apakah informasi itu sudah sesuai dan mengembangkan informasi yang dimiliki di dalam pikiran (tacit) melalui penulisan artikel karya ilmiah, pengembangan ilmu terapan dan juga bagaimana mahasiswa menyalurkan ilmu yang dimiliki sebagai bagian dari perluasan pengetahuan yang dimiliki. Hasil dari penelitian in akan melihat seberapa besar tingkatan literasi informasi mahasiswa Politeknik Negeri Batam.

Literasi informasi sendiri merupakan salah satu cara dalam meningkatkan modal sosial dalam persaingan global. Sumber kata literasi informasi berdasarkan sejarah muncul ketika Paul G. Zurkowski tahun 1974 mengeluarkan pernyataan bahwa orang yang literat informasi adalah orang yang terlatih dalam aplikasi sumber daya dalam pekerjaannya (Behren, 1994: Sulistyo-Basuki, n.d). Lebih lanjut, Zurkowski mengusulkan bahwa keterampilan literasi informasi harus diimplementasikan secara nasional karena urgensinya yang tidak dapat ditawar-tawar lagi berkaitan dengan prediksinya tentang perkembangan jumlah informasi baik dalam hal jumlah, media dan teknologinya yang akan terus meningkat (Baskoro, 2015 p.2). UNESCO dalam Flatform Information for All Programs 2008 menegaskan tentang pentingnya literasi informasi sebagai bagian dari masyarakat informasi, yang memberikan pengarahan dan penerangan untuk pengembangan, kemakmuran dan kebebasan. UNESCO juga menambahkan bahwa literasi informasi memberdayakan orang-orang di semua lapisan masyarakat untuk mencari, mengevaluasi, menggunakan dan menciptakan informasi secara efektif untuk mencapai tujuan pribadi, sosial, pekerjaan dan pendidikan mereka. Orang yang melek informasi mampu mengakses informasi tentang kesehatan, lingkungan, pendidikan dan pekerjaan mereka, dan membuat keputusan penting mengenai kehidupan mereka. Beberapa konsep literasi informasi diantaranya: (1) Christine Bruce (1997) mendefinisikan literasi informasi dalam 7 konsepsi yang dikenal dengan Seven Faces of Information Literacy. Bruce memberikan konsep seseorang yang literat salah satunya harus memiliki kemampuan untuk mengakses, melakukan evaluasi, mengorganisir dan menggunakan informasi untuk belajar, memecahkan masalah, membuat keputusan dalam konteks pembelajaran formal maupun informal di berbagai konteks. Sedangkan (2) The Society of College, National and University Libraries (SCONUL) mengeluarkan definisi bagaimana orang yang literat adalah orang yang memiliki kemampuan untuk mendemonstrasikan sebuah kesadaran bagaimana mereka mengumpulkan, 
menggunakan, mengatur, mensintesis, dan menciptakan informasi dan data secara etis dan akan memiliki keahlian informasi untuk menggunakannya secara efektif (2011). (3) A New Curriculum for Information Literacy (ANCIL,2012) memberikan definisi bahwa literasi informasi adalah rangkaian keterampilan, perilaku, pendekatan dan nilai-nilai yang begitu dalam terjalin dengan penggunaan informasi untuk menjadi elemen fundamental dari pembelajaran, ilmiah dan penelitian. Ini adalah ciri khas dari sarjana cerdas, warga informasi dan bijaksana, dan pelajar otonom. (4) Chartered Institute of Library Information Professionals (CILIP, 2013) mendefinisikan literasi informasi adalah mengetahui kapan dan mengapa anda membutuhkan informasi, dimana menemukannya, dan bagaimana mengevaluasinya, menggunakan dan mengkomunikasikanya dengan ber-etika.

Definisi dan kerangka yang dijelaskan sebelumnya menjelaskan bahwa literasi informasi memiliki banyak pengertian dari berbagai ahli dan komunitas dan dapat dikatakan bahwa literasi informasi merupakan kemampuan dan rangkaian keterampilan manusai dalam berperilaku, mengumpulkan, mengakses, menggunakan, mengatur, melakukan veluasi, menciptakan dan mengkomunikasikan atau menyebarkan informasi yang dimiliki dengan beretika dan efektif. Kompetensi ini yang menjadi bekal mahasiswa dalam melihat informasi sebagai sebuah kebutuhan, mengetahui bagaimana dan dimana mencari informasi yang dibutuhkan dan mengelola informasi dengan baik sehingga akan timbul sebuah pemahaman dan adanya peningkatan keterampilan dan pengetahuan. Persaingan global untuk lulusan Politeknik menjadi acuan dalam memahami pentingnya lliterasi informasi. Kemampuan literasi informasi termasuk didalamnya adalah kemampuan untuk belajar sepanjang masa agar pengetahuan yang dimiliki bertambah. Diao Ai Lien (2014) menambahkan untuk mempercepat proses pembelajaran, baik di tingkat individu maupun organisasi maka pengetahuan harus dikelola dengan baik. Menurut Australian and New Zealand Institute for Information Literacy (ANZIL, 2004) kemampuan literasi informasi dapat dilihat dalam kompetensinya, yaitu: (1) Mengenali kebutuhan informasi, (2) Menentukan sejauh mana informasi yang dibutuhkan, (3) Akses informasi secara efisien., (4) Kritis mengevaluasi informasi dan sumber-sumbernya, (5) Mengklasifikasikan, menyimpan, memanipulasi dan merumuskan kembali informasi yang dikumpulkan atau dihasilkan, (6) Menggabungkan informasi yang dipilih ke dalam basis pengetahuan mereka, (7) Menggunakan informasi secara efektif untuk belajar, menciptakan pengetahuan baru, memecahkan masalah dan membuat keputusan, (8) Mengerti, hukum, isu-isu sosial, politik dan budaya dalam penggunaan informasi (9) Akses dan menggunaan informasi secara etis dan legal, (10) Menggunakan informasi dan pengetahuan untuk kewarganegaraan partisipatif dan tanggung jawab sosial dan (11) Pengalaman literasi informasi sebagai bagian dari belajar mandiri dan belajar sepanjang hayat.

Penelitian ini mengikuti kompetensi yang dikeluarkan oleh American Library Association (ALA, 2000) adalah: (1) Menentukan sejauh mana informasi yang dibutuhkan.; (2) Akses informasi yang dibutuhkan secara efektif dan efisien, (3) Mengevaluasi informasi dan sumber-sumber secara kritis, (4) Menggabungkan informasi terpilih menjadi satu dasar pengetahuan dan (5) Menggunakan informasi secara efektif untuk mencapai tujuan tertentu. Tujuan penelitian adalah untuk mengetahui bagaimana tingkatan literasi informasi mahasiswa/i pada tingkat pertama, Manfaat penelitian ini adalah dapat membantu Politeknik Negeri Batam mengembangkan kemampuan literasi informasi pada mahasiswa yang berguna sebagai pembelajaran seumur hidup dan juga sebagai pijakan awal untuk pemantapan program literasi informasi di Politeknik Negeri Batam sehingga menghasilkan lulusan yang memiliki kemampuan professional dan non-professional sesuai dengan harapan dunia industri dan kompetensi literasi informasi menjadi dasar dalam menghadapi persaingan di dunia kerja dan menghasilkan lulusan yang memiliki kompetensi bertaraf nasional maupun internasional. 


\section{METODE}

Metode penelitian ini menggunakan pendekatan kuantitatif deskriptif. Pengambilan sampel dilakukan dengan teknik purposive sampling dengan kriteria yang dipilih adalah: (1) mahasiswa Politeknik Negeri Batam tingkat pertama, (2) mahasiswa penerima beasiswa bidikmisi. Jumlah populasi dalam penelitian ini sebanyak 1214 orang mahasiswa dari 12 program studi. Sampel yang diambil menggunakan rumus Slovin dan didapatkan hasilnya adalah 93 orang. Alat penelitian menggunakan skoring dengan skala Likert, yaitu: skor 1 menunjukkan jawaban kurang tepat, skor 2 menunjukkan jawaban Cukup Tepat, skor 3 jawaban Tepat, dan skor 4 adalah jawaban Sangat Tepat.

Penelitian ini menggunakan 7 standar kompetensi yang diberikan oleh ALA (2000) dengan aspek pertanyaan, yaitu: (a) Kemampuan menentukan informasi yang dibutuhkan (standar 1); (b) Kemampuan mengakses informasi yang dibutuhkan (standar 2); (c) Kemampuan mengevaluasi informasi dan sumber informasi yang didapatkan (standar 3) dan ; d) Kemampuan memahami bidang ekonomi, legal dan masalah sosial di sekitar dalam menggunakan informasi (standar 5)

Analisis data yang dilakukan pada penelitian ini adalah uji validitas untuk mengukur dan menilai apa yang dinilai dan validitas mencakup hubungan antara konstruksi dan indikatornya. Validitas merupakan langkah uji untuk yang dilakukan oleh peneliti untuk mengumpulkan data secara empiris untuk mendukung kesimpulan yang dihasilkan oleh nilai instrumen. Selain itu, analisis data juga melakukan uji reliabilitas. Uji reliabilitas sebagi alat uji jawaban dari responden yag menggunakan koesioner memiliki konsistensi. Jawaban responden dari kuesioner dikatakan konsisten jika jawaban seseorang terhadap pertanyaan adalah konsisten dan stabil dari waktu ke waktu (Ghozali, 2013). Uji selanjutnya adalah Uji Outlier dan hal penting untuk dilakukan dalam pengujian yaitu untuk mengetahui penyimpangan data terhadap rata-ratanya.

\section{HASIL DAN PEMBAHASAN}

Berdasarkan penelitian yang sudah dilakukan, maka hasil penelitian diuraikan sebagai berikut:

\section{Karakteristik Responden}

- Karakteristik responden berdasarkan jenis sekolah menengah dijelaskan pada gambar berikut:

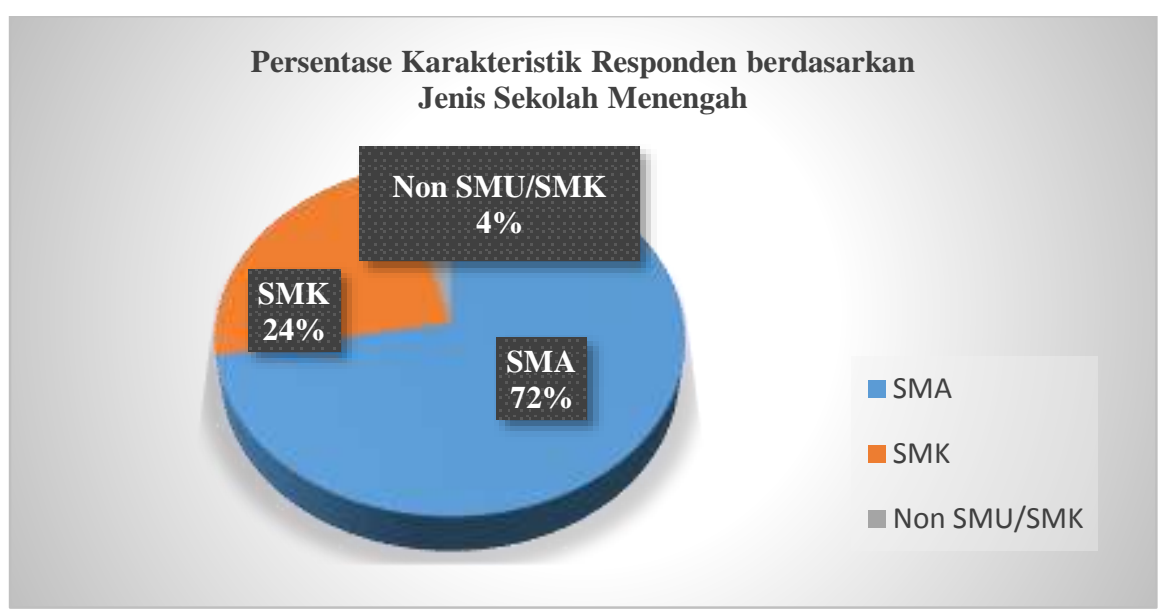

Gambar 1 Persentase Karakteristik Responden Berdasarkan Jenis Sekolah Menengah

(Sumber: Pengolahan data, 2018) 
Gambar 1 menunjukkan bahwa jenis sekolah menengah mayoritas mahasiswa/i Politeknik Negeri Batam adalah 72\% dari Sekolah Menengah Umum (SMU), sedangkan persentase untuk SMK (Sekolah Menengah Kejuruan) adalah 24\%, Sisanya adalah tidak menjelaskan dari SMU atau SMK. Hal ini sesuai dengan keadaan bahwa SMU di Batam lebih banyak dibandingkan SMK. Kesimpulan yang didapatkan dari gambar 1 tersebut bahwa dengan latar belakang pendidikan SMU masih dapat mengikuti mata kuliah di pendidikan vokasi. Subyek pelajaran yang diajarkan di SMU ini masih dikatakan memiliki hubungan dengan mata kuliah di Polibatam.

Data yang diambil dari populasi adalah mayoritas penerima beasiswa bidik misi dengan kriteria mahasiswa berprestasi dengan nilai rata-rata kelas adalah 8 dan memiliki latar belakang keluarga yang kurang mampu. Hasil ini ditemukan karena $90 \%$ mahasiswa bidik misi berasal dari pulau-pulau sekitar kota Batam dan memiliki orang tua yang berpenghasilan tidak menentu karena mayoritas adalah nelayan.

Faktor yang mempengaruhi kompetensi literasi mahasiswa adalah faktor sosial, ekonomi dan budaya yang di lingkungan keluarga, sekolah dan sekitar. Faktor sosial diantaranya adanya kesenjangan antara mahasiswa yang tinggal di pusat kota Batam dan mahasiswa yang berdomisili di pulau sekitar Batam. Akses transportasi juga menjadi pendorong faktor sosial karena transportasi antar pulau menggunakan perahu sehingga informasi yang ingin didapatkan tidak sebanyak informasi yang didapatkan mahasiswa yang tinggal di pusat kota Batam. Faktor ekonomi jelas menjadi pendorong karena penghasilan orang tua mahasiswa adalah nelayan dan hanya mengandalkan perekonomian keluarga dari alam sehingga akses informasi tidak semudah bila orangtua mahasiswa memiliki penghasilan yang layak. Selain kedua faktor tersebut, budaya juga mempengaruhi karena Batam merupakan daerah yang penduduknya beragam dan banyak dipengaruhi budaya dari masyarakat pendatang sehingga informasi yang ada banyak dan memaksa mahasiswa menerima semua informasi tanpa mengevaluasi apakah informasi yang diterima dan didapatkan itu berguna.

- Karakteristik responden berdasarkan jenis program studi dijelaskan pada gambar berikut:

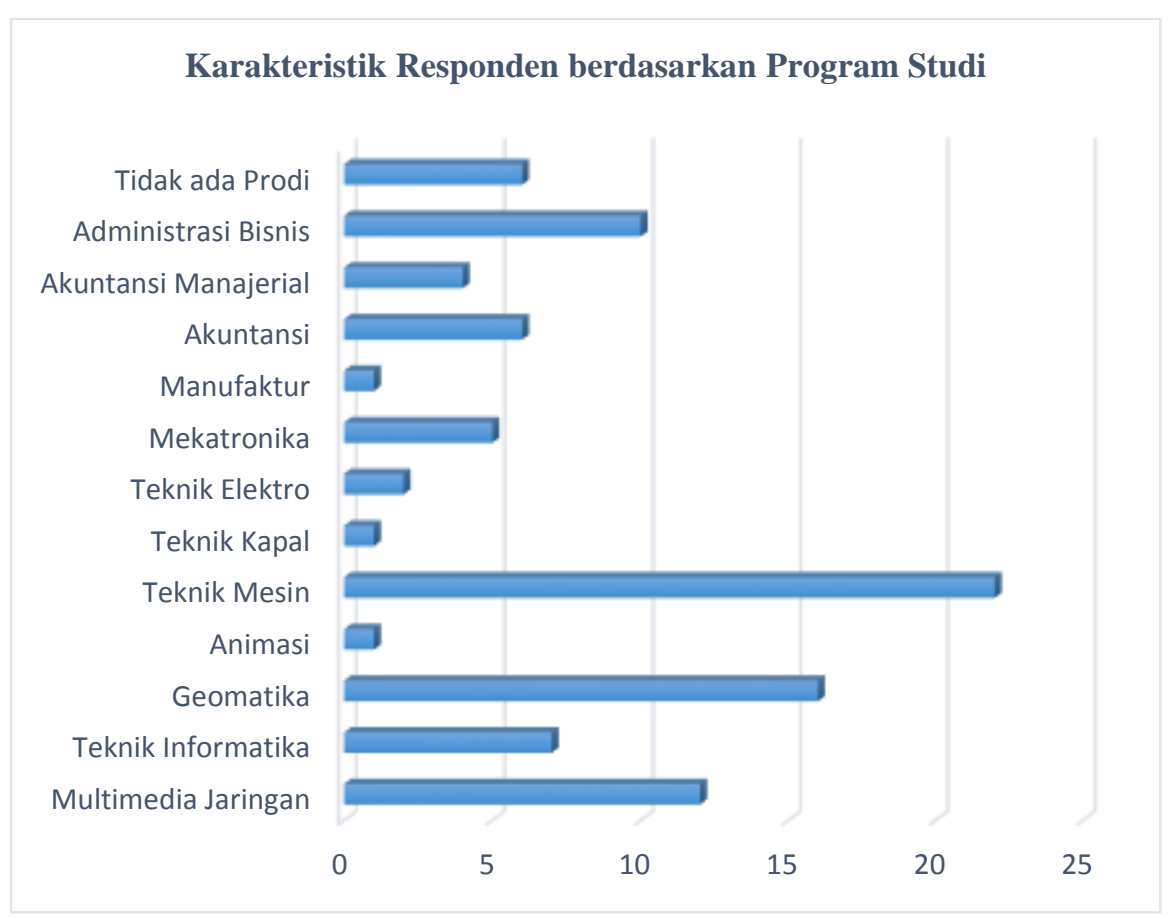

Gambar 2 Karakteristik Responden Berdasarkan Jenis Program Studi

(Sumber: Pengolahan data, 2018)

Gambar 2 menunjukkan mayoritas responden adalah mahasiswa dari program studi Teknik Mesin dan berjumlah 22 orang responden dan program studi Geomatika berjumlah 16 orang. Teknik informatika berjumlah 12 orang dan administrasi bisnis berjumlah 10 orang. Responden yang paling kecil adalah teknik animasi dan 
teknik manufaktur hanya berjumlah masing-masing 1 orang. Hal ini dikarenakan kedua program studi tersebut baru dibuka dan mahasiswa peminat program studi tersebut tidak banyak dibandingkan program studi lain.

Pengambilan sampel dilakukan berdasarkan komposisi mahasiswa yang disesuaikan dengan penerima beasiswa bidikmisi. Penerimana bidikmisi di Politeknik Negeri hanya menduduki sekitar 20\% dari jumlah keseluruhan mahasiswa.

\section{Hasil Penelitian}

Berdasarkan ALA (2000) bahwa kompetensi literasi informasi memiliki 7 kompetensi mulai dari indentifikasi, mengetahui jangkauan, merencanakan, mengumpulkan, mengevaluasi, mengelola dan melakukan presentasi. Kemampuan ini berdasarkan 4 standar yaitu mengenai kemampuan menentukan informasi yang dibutuhkan, kemampuan mengakses informasi yang dibutuhkan, mengevaluasi informasi dan sumber informasi yang didapatkan dan kemampuan memahami ekonomi, legal dan masalah sosial di sekitar dalam menggunakan informasi. Hasil interpretasi standar literasi informasi digambarkan sebagai berikut:

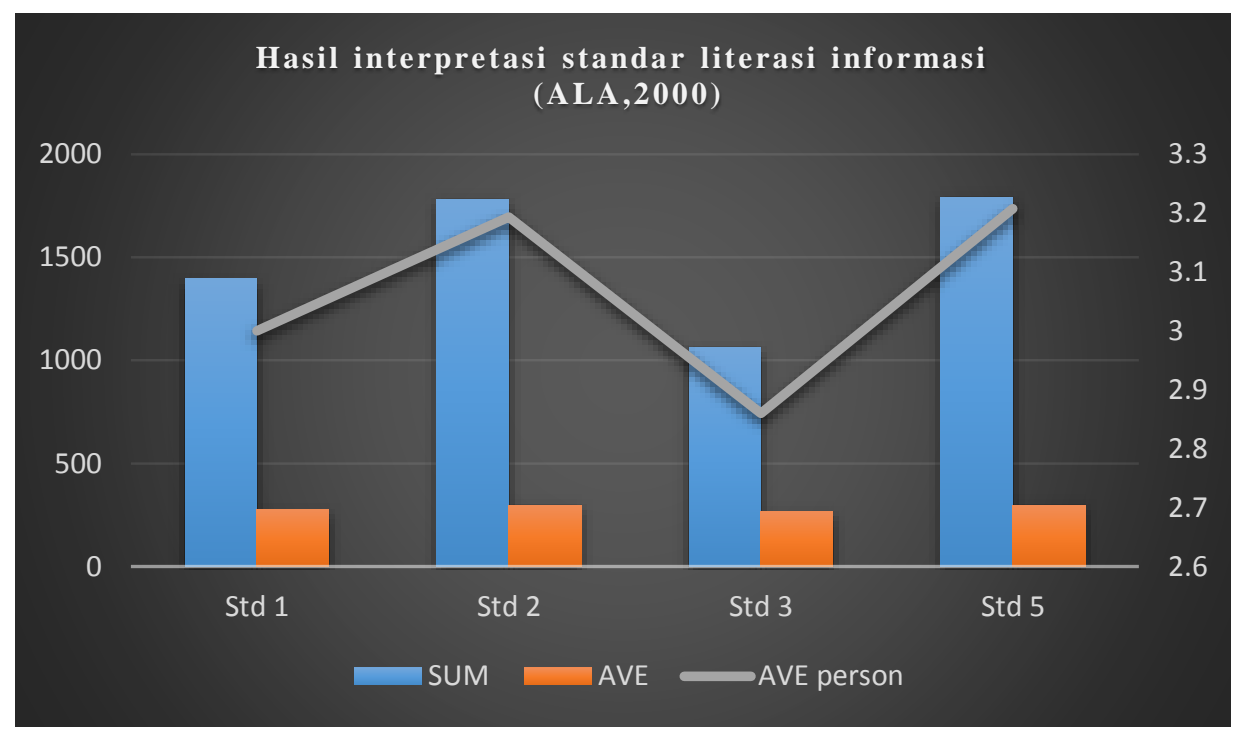

Gambar 3 hasil interpretasi standar literasi informasi (ALA,2000)

(Sumber : Pengolahan data, 2018)

Berdasarkan gambar 3 hasil interpretasi standar literasi informasi menurut ALA (2000) bahwa: (1) standar 1 dari 5 pertanyaan yang diajukan secara keseluruhan berjumlah 1395 dan rata-rata keseluruhan adalah 279 dengan nilai 3 dan dikategorikan sebagai jawaban Tepat,; (2) standar 2 dari 6 pertanyaan yang diajukan secara keseluruhan berjumlah 1782 dan rata-rata keseluruhan adalah 297 dengan nilai 3,19 dikategorikan sebagai jawaban Tepat (3) standar 3 dari 4 pertanyaan yang diajukan secara keseluruhan berjumlah 1064 dan rata-rata keseluruhan berjumlah 266 dengan nilai 2,86 sebagai jawaban Cukup Tepat dan (4) standar 5 dari 6 pertanyaan yang diajukan secara keseluruhan berjumlah 1789 dan rata-rata keseluruhan adalah 298 dengan nilai 3,2 dikategorikan sebagai jawaban Tepat.

Jadi, dapat dipastikan bahwa rata-rata dari setiap pertanyaan yang diajukan adalah 3,06 berarti semua jawaban kategori TEPAT. Merunut dari standar yang diproyeksikan ALA (2000) mengenai kompetensi literat bahwa mahasiswa/i Politeknik Negeri Batam masuk dalam kategori BAIK. Kategori tersebut dapat dilihat dari standar yang ditentukan, yaitu: (1) Bagaimana mahasiswa menentukan informasi yang tepat dalam menjawab tugas yang diberikan oleh dosen, mengetahui informasi apa yang dibutuhkan, dan mengetahui bagaimana cara menggunakan koleksi perpustakaan.; (2) Kemampuan mahasiswa menggunakan sumber informasi internet dan menelusur 
informasi apa yang terdapat di dalam sebuah situs internet untuk mendukung pembelajaran, mengetahui bagaimana penggunaan Boolean Operator ketika menelusur menganalisa dokumen dengan membaca dengan tepat.; (3) Kemampuan untuk mengevaluasi informasi dari sumber informasi yang didapatkan, seperti kemampuan mengetahui langkah-langkah menganalisa dokumen yang didapatkan dari internet, mengetahui kualitas internet dan membedakan antara sumber informasi terpercaya atau hoax, mengetahui bagaimana cara menelusur jejak digital dan mengutip dari artikel jurnal, dan (4) Kemampuan dalam memahami isu yang terjadi di dalam kehidupan masyarakat dan yang beredar di internet, media massa dan sumber informasi lain.

\section{- Perbandingan tingkatan literasi informasi antar jurusan Teknik}

Perbandingan tingkatan literasi antar jurusan teknik yang ada di Politeknik Negeri Batam yaitu Teknik informatika yang terdiri dari teknik informatika, multimedia jariangan, geomatika dan animasi. Teknik mesin terdiri dari teknik mesin dan teknik kapal, dan teknik elektronika terdiri dari teknik elektro, mekatronika dan manufaktur. Perbandingan ketiga jurusan digambarkan sebagai berikut:

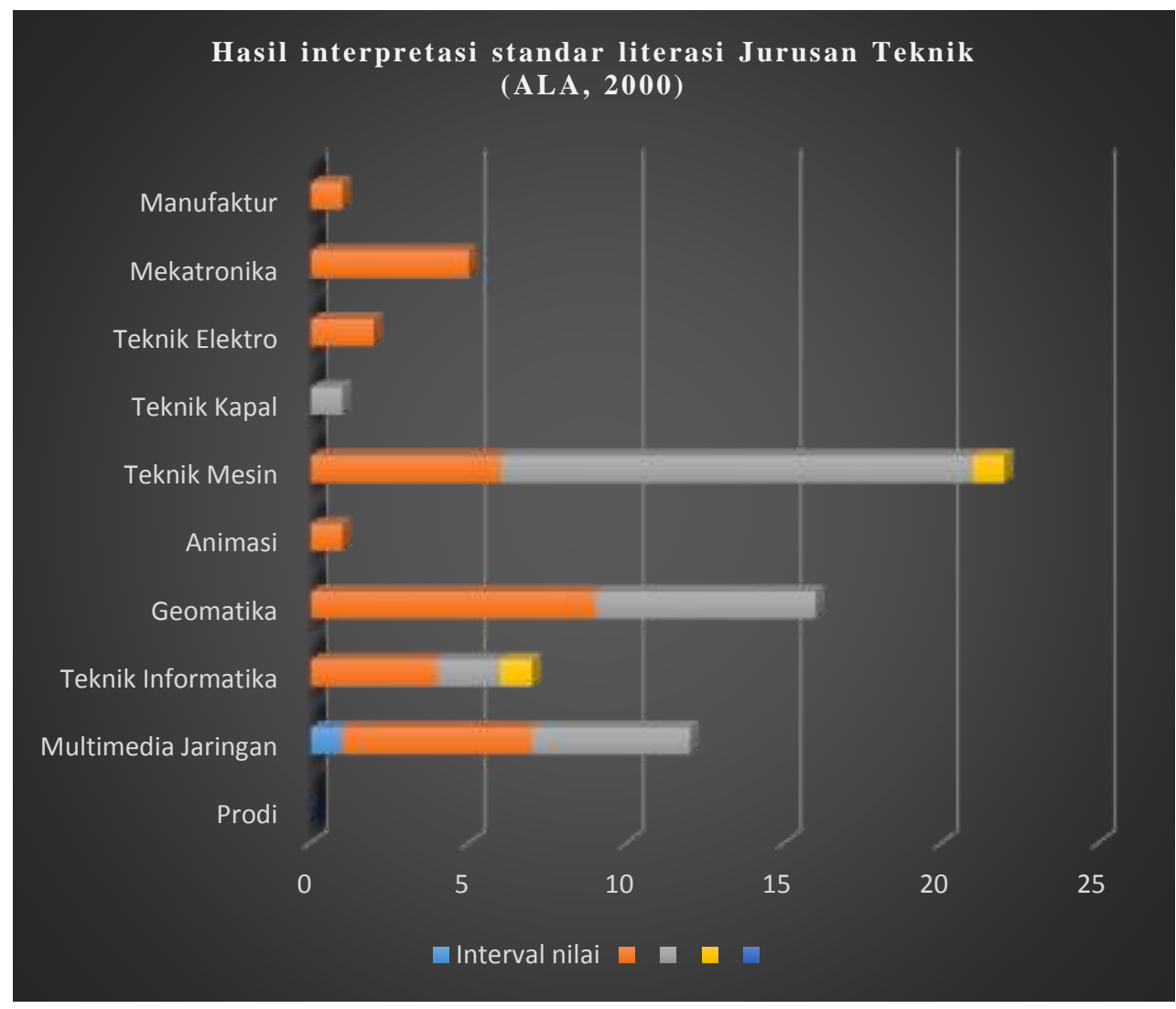

Gambar 4 hasil interpretasi standar literasi informasi jurusan Teknik (ALA,2000)

(Sumber : Pengolahan data, 2018)

Gambar 4 menunjukkan bahwa terdapat hanya 1 responden yang memiliki nilai tertinggi dengan kategori Sangat Baik di teknik informatika. Secara keseluruhan antar jurusan teknik kemampuan mahasiswa menjawab masuk ke dalam kategori Baik dengan interval nilai. Kategori baik dapat diartikan bahwa mahasiswa di teknik sudah memiliki kompetensi untuk mengetahui informasi yang dibutuhkan, menentukan sumber informasi dan juga memahami masalah di sekitar dengan penggunaan teknologi. Penggunaan teknologi di lingkungan Politeknik Negeri Batam mendukung untuk penelusuran informasi terkini secara cepat sehingga gap teknologi sulit ditemukan seiring dengan generasi milenial yang tidak dapat dipisahkan dari penggunaan teknologi dan serba digital. 


\section{- Perbandingan tingkatan literasi informasi Manajemen Bisnis dan jurusan Teknik}

Perbandingan literasi informasi mahasiswa manajemen bisnis dan jurusan teknik dapat digambarkan sebagai berikut:

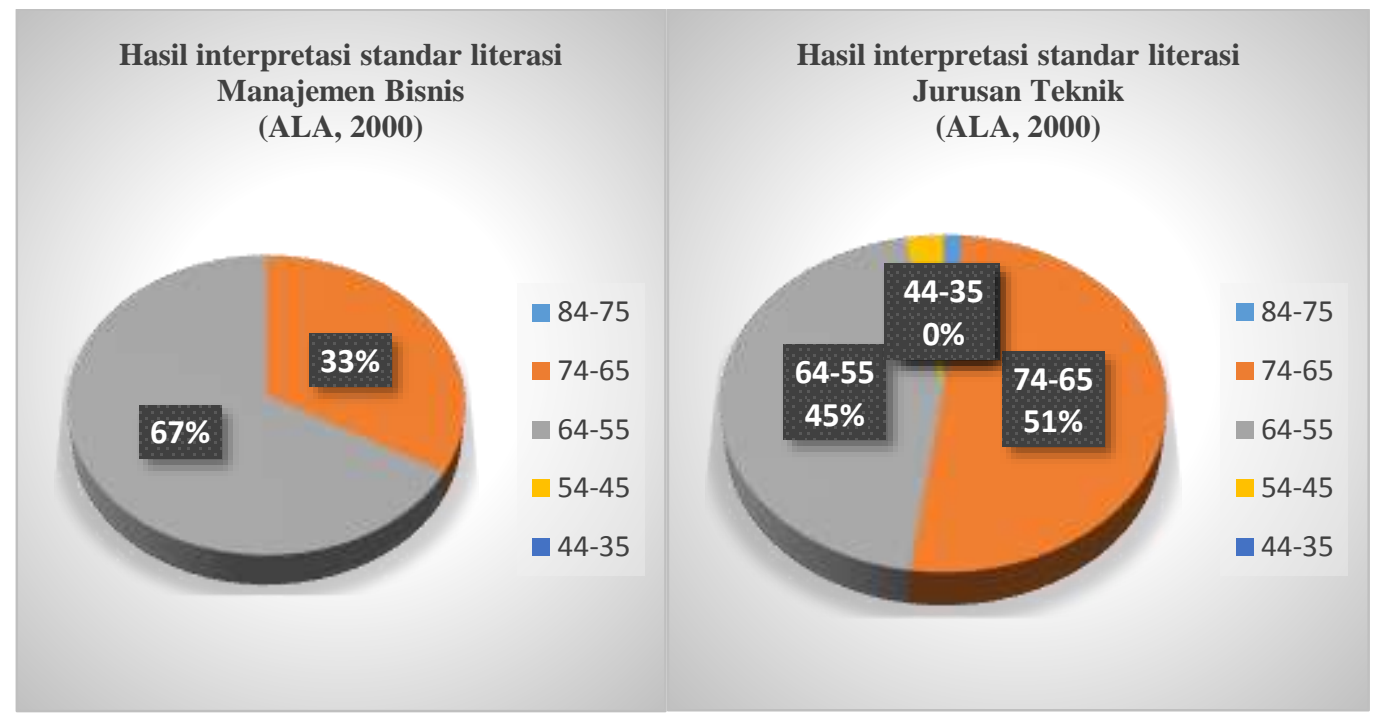

Gambar 5 hasil interpretasi standar literasi informasi jurusan manajemen bisnis dan jurusan teknik

(ALA,2000)

(Sumber : Pengolahan data, 2018)

Gambar 5 menunjukkan bahwa 67\% responden mahasiswa yang berasal dari jurusan mahasiswa bisnis berada dalam kategori Cukup dengan interval nilai 64-55. Sedangkan keseluruhan jurusan teknik memiliki 51\% mahasiswa berada di interval 74-65. Hal ini menunjukkan bahwa tingkatan literasi informasi mahasiswa teknik lebih tinggi dibandingkan dengan jurusan manajemen bisnis. Hal ini dikarenakan karena teknik informatika lebih terbiasa menggunakan digital teknologi yang berkaitan dengan teknologi yang update terus menerus. Selain itu, subyek mata kuliah yang diajarkan di teknik informatika dan teknik lainnya lebih banyak menggunakan teknologi sebagai bagian dari proses belajar mengajar. Sedangkan untuk 12 responden yang tidak memasukkan nama program studinya, dapat digambarkan sebagai berikut:

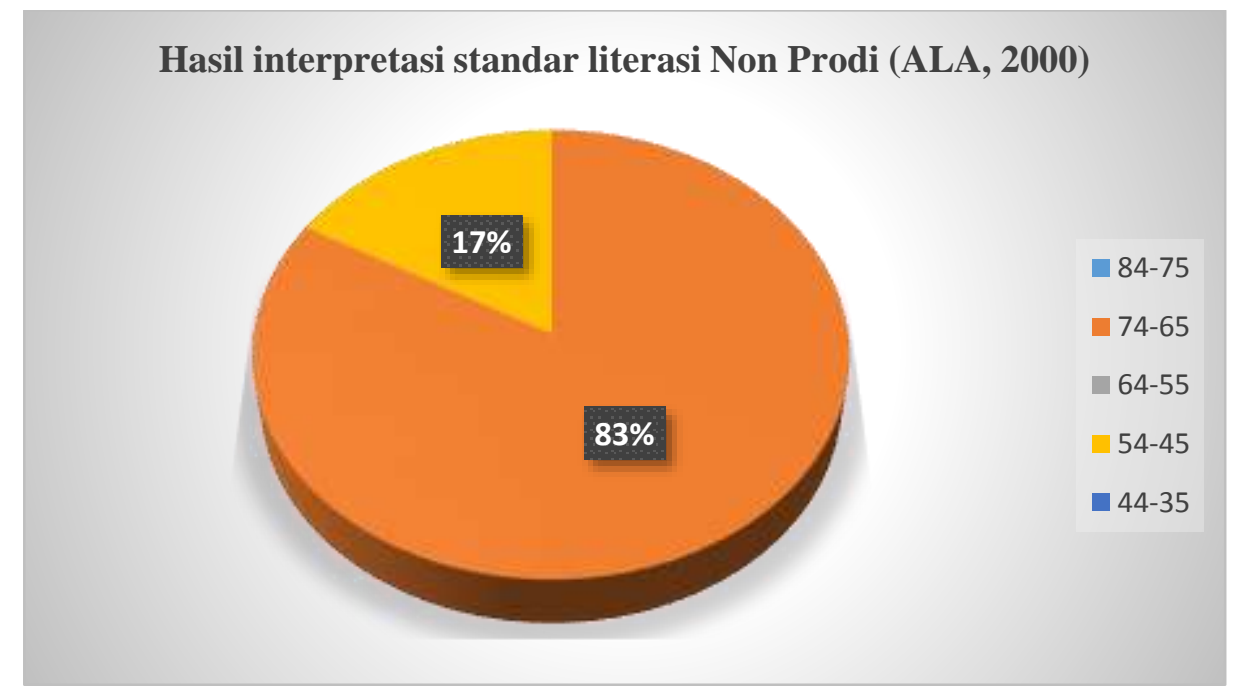

Gambar 6 hasil interpretasi standar literasi non prodi (ALA,2000)

(Sumber : Pengolahan data, 2018) 
Gambar 6 menunjukkan bahwa 5 responden atau 83\% dari total responden yang tidak diketahui program studinya memiliki nilai 74-65 dengan kategori Baik dan sisanya 17\% atau hanya 1 orang yang mendapat niali 5445 dengan kategori kurang. Hal ini menunjukkan bahwa secara keseluruhanan tingkat literasi informasi mahasiswa masih dikatakan Baik.

\section{KESIMPULAN}

Berdasarkan hasil analisa yang dilakukan melalui data deskriptif, kesimpulan dari penelitian ini adalah tingkatan literasi informasi mahasiswa Politeknik antar jurusan adalah bahwa mahasiswa dari jurusan teknik seperti teknik informatika, teknik mesin dan teknik elektro yang masing-masing didalamnya memiliki program studi yang berkaitan dengan teknologi memiliki tingkatan literasi lebih tinggi dibandingkan mahasiswa dari jurusan manajemen bisnis. Hal ini dilihat dari penggunaan digital teknologi yang lebih banyak porsinya dibandingkan di jurusan manajemen bisnis. Mahasiswa jurusan teknik memiliki kesempatan lebih besar dan terbiasa untuk menggunakan digital teknologi. Latar belakang sekolah menengah juga mempengaruhi literasi informasi bahwa mahasiswa yang literat sudah terbiasa memahami konteks dari informasi.

Hasil yang didapatkan penelitian ini juga menyangkut mengenai standar kompetensi literasi informasi dan didapatkan hasil analisanya bahwa mahasiswa Politeknik Negeri Batam kategori nilai Baik. Nilai tertinggi 3,2 berada pada standar 2 mengenai pemahaman bagaimana menggunakan sumber informasi dan standar 5 mengenai pemahaman memahami masalah yang terjadi disekitarnya. Standar kompetensi yang nilainya kurang dari 3 adalah standar 3 mengenai bagaimana melakukan evaluasi terhadap informasi yang didapatkan. Hal ini dilihat masih banyaknya mahasiswa belum dapat mengevaluasi sumber informasi yang tepat dijadikan referensi.

Saran dalam penelitian ini adalah bahwa untuk mengetahui tingkatan literasi informasi mahasiswa harus dilakukan secara berkala. Hal ini dikarenakan karena literasi informasi merupakan kompetensi dasar untuk mahasiswa dalam menghadapi persaingan global. Literasi informasi diperlukan mahasiswa sebagai usaha belajar sepanjang hayat. Selain literasi informasi diperlukan maka selanjutnya adalah literasi digital untuk penelitian selanjutnya.

\section{DAFTAR PUSTAKA}

Gullbekk, E., Boyum, I., Bystrom, K. (2015). Interdisciplinarity and information literacy: Librarians' competencies in emerging settings of higher education. Proceedings of the Association for Information Science and Technology, diakses 7 Maret 2018 dari http://onlinelibrary.wiley.com/doi/10.1002/pra2.2015.145052010079/full

Lien, D.A.,Agustin, W.G., Dora, A., Santi, K. (2010) Literasi informasi: 7 langkah knowledge management. Jakarta: Penerbit Universitas Atmajaya

Maurer, A., Schlogl, C., Dreisiebner, S. (2016). Comparing information literacy of student beginners among different branches of study. Libellarium, IX (2): 309-319.

Palys, T. (2008). Purposive sampling. In L.M. Given (Ed.)The Sage Encyclopedia of Qualitative Research Methods.(Vol.2). Sage: Los Angeles

Schuster, S. M. (2007). Information literacy as a core value. Biochemistry and molecular biology education. 35 (5) : 372-373.

Siagian, J. (2008). Urgensi Literasi Informasi dalam Kurikulum Berbasis Kompetensi di Perguruan Tingi. Pustaka. 4(2): 34-44.

Journal of Digital Education, Communication, and Arts • Vol. 2 • No. 1 • March 2019 • E-ISSN: 2614-6916 |53 
Sulistyo-Basuki. (2010). Metode penelitian. Jakarta: Penaku.

Sulistyo-Basuki. (2013) Literasi Informasi diakses tanggal 1 April 2016 dari https://sulistyobasuki.wordpress.com/2013/03/25/literasi-informasi-dan-literasi-digital/

UNESCO. Information for All Programme: Information Literacy., diakses 7 Maret 2018 dari http://www.unesco.org/new/en/communication-and-information/intergovernmental-programmes/informationfor-all-programme-ifap/priorities/information-literacy/

54 | Maryani Septiana Et Al.: Perbandingan Literasi Informasi Mahasiswa Pemula ... 